\title{
PENGARUH DIVERSIFIKASI PENDAPATAN TERHADAP KINERJA BANK
}

\author{
Aryanti Sariartha Sianipar \\ Universitas Widyatama \\ e-mail: aryanti.sariartha@widyatama.ac.id
}

\begin{abstract}
This study examines the effect of income diversification on bank performance. This study also empirically examines the effect of income diversification on performance based on size of the banks. The proxies for income diversification are non-interest income, fee income, and trading income, while the performance indicators comprise of market risk, accounting risk, market value, and accounting performance. By employing panel data of listed banks in Indonesia from the period 2004-2012, this study finds that diversification of income negatively affects market risk. The source of income that leads to lower the risk is fee-based income. This study also reveals that income diversification has a positive impact on profitability but do not significantly affect firm value. The negative effect of income diversification toward beta is found larger for large banks relative to small banks.
\end{abstract}

Keywords: Income Diversification, Non-interest Income, Bank Risk, Profitability, Bank Performance.

\begin{abstract}
Abstrak
Penelitian ini bertujuan untuk menguji pengaruh diversifikasi pendapatan terhadap kinerja bank. Selain itu penelitian ini juga menguji pengaruh diversifikasi pendapatan terhadap kinerja pada bank besar dan bank kecil. Diversifikasi pendapatan diukur dengan proporsi pendapatan non-bunga, pendapatan fee, dan pendapatan trading, sedangkan kinerja bank diukur dengan risiko pasar, risiko akuntansi, nilai perusahaan, dan kinerja akuntansi. Sampel penelitian adalah bank-bank yang terdaftar di Bursa Efek Indonesia periode 2004-2012. Data yang digunakan adalah data panel. Berdasarkan regresi terhadap data panel ditemukan bahwa diversifikasi pendapatan mampu menurunkan risiko pasar, dan sumber pendapatan yang mampu menurunkan risiko adalah pendapatan fee. Diversifikasi pendapatan tidak berpengaruh terhadap nilai perusahaan, namun berpengaruh positif terhadap profitabilitas. Pada bank besar ditemukan pengaruh diversifikasi pendapatan yang lebih negatif terhadap beta saham bila dibandingkan dengan bank kecil.
\end{abstract}

Kata kunci: Diversifikasi Pendapatan, Pendapatan Non-bunga, Risiko Bank, Profitabilitas, Kinerja Bank.

\section{PENDAHULUAN}

Teori portofolio menyatakan bahwa diversifikasi investasi akan memberikan manfaat penurunan risiko terutama risiko spesifik perusahaan. Hal ini mendorong pengelola bank melakukan diversifikasi usaha. Banyak bank tidak lagi fokus pada aktivitas penyaluran kredit, namun sudah memperluas aktivitasnya ke lini bisnis yang melayani nasabah dalam perdagangan dan berinvestasi pada surat-surat berharga, menjual asuransi, menjadi penjamin emisi, serta melayani aktivitas-aktivitas transaksi Akibatnya, pendapatan operasional non- bunga menjadi semakin meningkat proporsinya dibandingkan pendapatan yang berasal dari aktivitas penyaluran kredit atau disebut dengan pendapatan bunga.

Data perbankan pada Statistik Perbankan Indonesia yang dimulai tahun 2006 hingga 2012 mengungkap bahwa terjadi peningkatan proporsi pendapatan non-bunga terhadap pendapatan operasional pada bankbank di Indonesia. Informasi detil tentang struktur pendapatan bank tersebut dapat dilihat pada grafik 1 . 


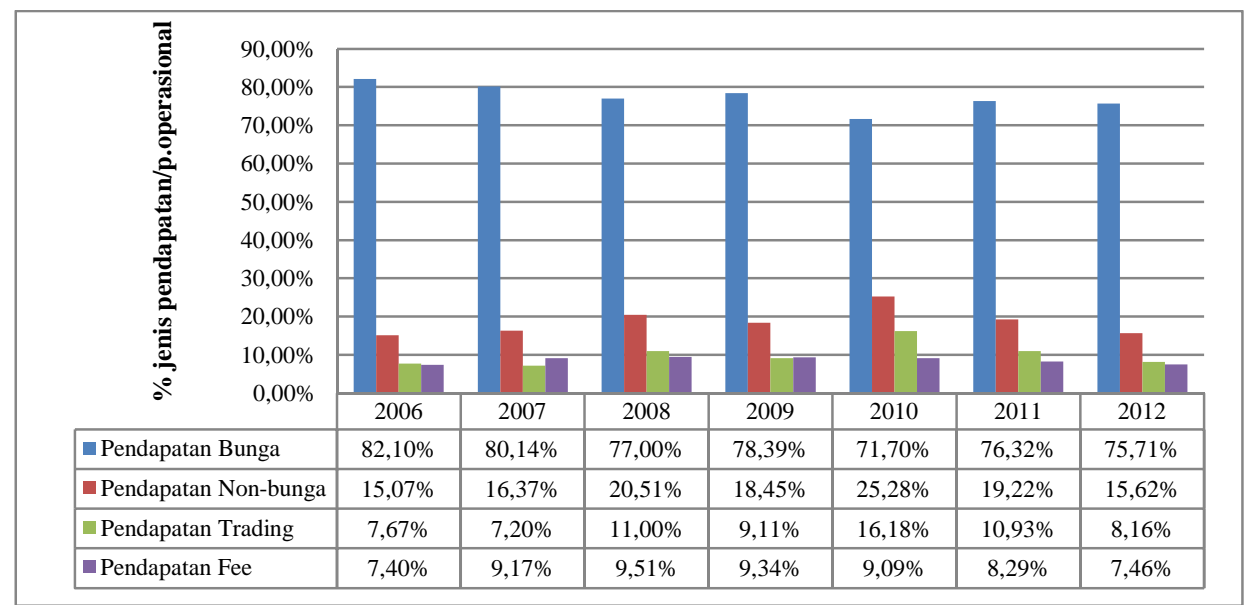

Grafik 1. Struktur Pendapatan Bank Umum Periode 2006-2012 Sumber: Bank Indonesia (2012; 2013) (data diolah)

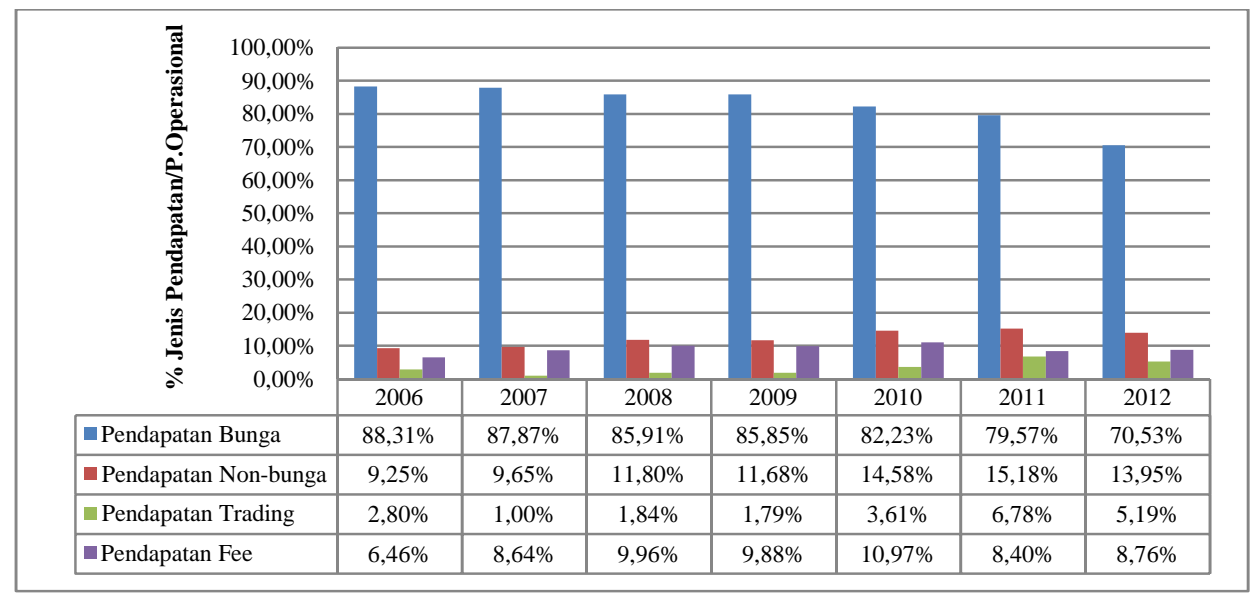

Grafik 2. Struktur Pendapatan Bank Persero Periode 2006-2012 Sumber: Bank Indonesia (2012; 2013) (data diolah)

Penelitian terkait diversifikasi pendapatan di industri perbankan telah dilakukan di beberapa negara seperti di Amerika dan Eropa (Baele et al., 2007; Laeven and Levine, 2007; Chiorazzo et al., 2008; Sanya dan Wolve, 2011; Brighi dan dn Venturelli, 2014), serta Asia dan Afrika (Vennet, 2002; Acharya et al., 2006; Deng et al., 2007; Elyasiani dan Wang; 2012; Sawada, 2013; Zhou, 2014; Albssan, 2015 ). Penelitian mengenai diversifikasi pendapatan di Indonesia juga telah dilakukan oleh beberapa peneliti dan memberikan hasil bahwa diversifikasi pendapatan bank berpengaruh signifikan pada risiko dan probabilitas kebangkrutan perusahaan (Hidayat et al., 2012; Kusuma, 2012). Penelitian-penelitian mengenai pengaruh diversifikasi pendapatan bank terhadap kinerja memberikan hasil yang kontradiktif. Beberapa penelitian menemukan bahwa diversifikasi pendapatan bank memberi- kan efek penurunan kinerja (Stiroh dan Rumble, 2006; Laeven and Levine, 2007; Berger et al., 2010). Namun terdapat juga beberapa studi yang menemukan diversifikasi pendapatan berdampak positif terhadap kinerja bank (Baele et al., 2007; Elsas et al., 2010; Sawada, 2013).

Studi mengenai pengaruh diversifikasi pendapatan terhadap risiko juga memberikan hasil yang kontradiktif. Stiroh (2006) mengungkapkan bahwa diversifikasi pendapatan di Amerika meningkatkan risiko bank. Baele et al. (2007) dan Sawada (2013) menemukan hasil yang berbeda, yaitu semakin menurunnya risiko non-sistematis dari semakin meningkatnya pendapatan non-bunga. Studi di Indonesia dilakukan oleh Hidayat et al. (2012) menemukan bahwa diversifikasi pendapatan meningkatkan risiko bank. Selain itu Kusuma (2012) menemukan bahwa pendapatan non-bunga 
menurunkan risiko sistematis bank. Studi-studi terdahulu juga menemukan bahwa sumber pendapatan yang berbeda memiliki dampak yang berbeda terhadap risiko. Sumber pendapatan dari fee dan trading meningkatkan risiko (Hidayat et al., 2012), sementara Kusuma (2012) menemukan fee income menurunkan risiko dan trading income meningkatkan risiko. Lapetit et al. (2008) menemukan bahwa di Eropa fee income meningkatkan risiko. Studi yang dilakukan di Indonesia masih terbatas pada pengaruh diversifikasi pendapatan terhadap risiko, belum terdapat studi yang menguji pengaruh diversifikasi terhadap kinerja bank. Oleh sebab itu penelitian ini berusaha untuk mengisi gap tersebut.

Penelitian terdahulu juga menemukan bahwa keputusan diversifikasi pada bank besar dan bank kecil memberikan dampak yang berbeda terhadap risiko (Lapetit et al., 2008; Hidayat et al., 2012; Kusuma, 2012). Mercieca et al. (2007) menemukan bahwa bank kecil menghadapi risiko yang semakin meningkat dengan semakin tingginya proporsi pendapatan non-bunga dan trading income. Bank kecil memiliki sumber daya dan keahlian karyawan yang terbatas. Jika dampak diversifikasi pendapatan terhadap risiko berbeda berdasarkan ukuran bank, maka sistem pengawasan yang berbeda perlu diterapkan oleh regulator perbankan. Penelitian ini bertujuan menguji pengaruh diversifikasi pendapatan terhadap risiko dan kinerja bank. Pembahasan dalam artikel ini akan dibagi ke dalam lima bagian. Pada bagian kedua akan dibahas mengenai penelitian terdahulu terkait diversifikasi pendapatan, di bagian ketiga akan dibahas metode penelitian, di bagian keempat akan dibahas hasil penelitian, dan di bagian terakhir akan dibahas kesimpulan.

\section{KAJIAN PUSTAKA}

\section{Pengaruh Diversifikasi Pendapatan Bank terhadap Risiko}

Stiroh dan Rumble (2006) meneliti financial holding companies (FHCs) di Amerika periode 1997-2002 dan menemukan bahwa pendapatan non-bunga meningkatkan risiko deviasi standar ROE dan deviasi standar ROA. Hal ini disebabkan aktivitas diversifikasi FHCs memiliki volatilitas yang tinggi dan terjadinya crossselling. Penelitian sebelumnya juga dilakukan dengan pendekatan portofolio (Stiroh, 2006) dan hasilnya diversifikasi pendapatan meningkatkan risiko total, sistematis, dan nonsistematis. Meningkatnya risiko disebabkan masalah keagenan internal bank. Baele et al. (2007) yang meneliti bank-bank di Eropa periode 1989-2004 menemukan bahwa diversifikasi pendapatan menurunkan risiko non-sistematis. Penjelasan untuk penemuan tersebut adalah rendahnya korelasi antara berbagai sumber pendapatan bank. Kusuma (2012) meneliti bank-bank di Indonesia periode 20052009 dan menemukan bahwa pendapatan nonbunga berpengaruh negatif terhadap risiko sistematis. Berdasarkan konteks Indonesia diharapkan diversifikasi mampu menurunkan risiko karena masih terdapat potensi skala ekonomi dan economies of scope yang bisa diperoleh bank.

$\mathrm{H}_{1 \mathrm{a}}$ : Diversifikasi pendapatan berpengaruh negatif terhadap risiko.

Aktivitas diversifikasi pendapatan menghasilkan dua jenis pendapatan, yaitu fee income dan trading income. Penelitian terdahulu di Jepang dengan menggunakan periode mulai tahun 1999-2011 memberikan bukti bahwa fee income mampu menurunkan risiko non-sistematis (Sawada, 2013). Pendapatan yang bersumber dari fee dipandang sebagai pendapatan yang lebih stabil dibanding sumber pendapatan lainnya. Lapetit et al. (2008) menunjukkan bahwa terdapat peningkatan risiko total dan non-sistematis bank-bank di Eropa jika semakin terlibat dalam aktivitas yang menghasilkan pendapatan fee. Hal tersebut disebabkan volatilitas fee income lebih tinggi dibandingkan pendapatan dari kredit serta tingginya biaya karyawan dan teknologi tambahan untuk aktivitas tersebut. Hidayat et al. (2012) menemukan hal yang sama di Indonesia dengan periode penelitian 2002-2008. Bertentangan dengan dua studi tersebut, studi Kusuma (2012) dengan periode penelitian 2005-2009 menemukan bahwa fee income berpengaruh negatif terhadap risiko sistematis. Hal itu disebabkan investor masih memandang fee income sebagai sumber pendapatan yang lebih stabil. Berdasarkan alasan tersebut dan adanya potensi economies of scope maka dirumuskan hipotesis sebagai berikut:

$\mathrm{H}_{1 \mathrm{~b}}$ : Fee income berpengaruh negatif terhadap risiko. 
Penelitian yang menguji pengaruh trading income terhadap risiko memberikan hasil yang bervariasi (Sawada, 2013; Hidayat $e t$ al., 2012; Kusuma, 2012; Lapetit et al., 2008; Mercieca et al., 2007). Bank-bank di Jepang mengalami penurunan risiko non-sistematis dan risiko total (Sawada, 2013). Hal itu disebabkan regulasi yang tidak memperbolehkan bankbank di Jepang untuk bertransaksi pada saham sehingga volatilitas pendapatannya lebih rendah. Lapetit et al. (2008) menemukan trading income tidak berpengaruh terhadap risiko bankbank di Eropa. Kusuma (2012) dan Hidayat et al. (2012) menemukan bahwa trading income meningkatkan risiko bank-bank di Indonesia, karena adanya cross-selling. Meningkatnya posisi bank pada kurs dan surat-surat berharga menyebabkan volatilitas pendapatan trading lebih tinggi.

$\mathrm{H}_{1 \mathrm{c}}$ : Trading income berpengaruh positif terhadap risiko.

\section{Pengaruh Diversifikasi Pendapatan Ter- hadap Kinerja Bank}

Beberapa penelitian menemukan efek positif diversifikasi pendapatan terhadap kinerja bank (Sawada, 2013; Elsas et al., 2010; Baele et al., 2007). Peningkatan kinerja tersebut ditunjukkan dengan semakin meningkatnya nilai pasar bank. Hal tersebut disebabkan investor memandang diversifkasi mampu menstabilkan pendapatan bank. Beberapa studi lainnya menemukan diversifikasi pendapatan menurunkan kinerja bank sebab konflik keagenan yang terjadi di bank menutupi manfaat economies of scope, dan bank terlibat dalam aktivitas yang meningkatkan volatilitas pendapatan (Berger $e t$ al., 2007; Laeven and Levine, 2007). Konteks Indonesia diharapkan aktivitas diversifikasi mampu meningkatkan kinerja bank karena aktivitas tersebut mampu menstabilkan pendapatan bank. Berdasarkan hal tersebut maka dirumuskan hipotesis:

$\mathrm{H}_{2}$ : Diversifikasi pendapatan berpengaruh positif terhadap kinerja bank.

\section{Pengaruh Diversifikasi Pendapatan terhadap Risiko pada Bank Besar dan Bank Kecil}

Lapetit et al. (2008) dan Mercieca et al. (2008) menemukan bahwa bank-bank kecil di Eropa mengalami peningkatan risiko ketika diversifikasi pendapatan semakin tinggi. Hal tersebut disebabkan bank-bank kecil melakukan diversifikasi pendapatan namun tidak memiliki keahlian yang cukup dalam mengelola aktivitas tersebut. Berbeda dengan studi di Eropa, studi Hidayat et al. (2012) menemukan pendapatan non-bunga meningkatkan risiko pada bankbank besar di Indonesia. Hal ini disebabkan bank-bank besar cenderung memiliki proporsi pendapatan non-bunga yang lebih tinggi dan kurang berkembangnya industri perbankan di Indonesia. Selain itu bank-bank besar memiliki keahlian manajemen yang lebih baik dan teknologi yang lebih baik. Berdasarkan hal tersebut dirumuskan hipotesis:

$\mathrm{H}_{3}$ : Pengaruh diversifikasi pendapatan terhadap risiko lebih negatif pada bank besar dibandingkan bank kecil.

\section{METODE PENELITIAN}

\section{Sampel Penelitian}

Penelitian ini melibatkan 27 bank yang terdaftar di Bursa Efek Indonesia periode 20042012. Bank-bank yang dijadikan sampel adalah bank-bank devisa. Hal tersebut ditentukan untuk menghindari tidak terdapatnya proporsi trading income karena bank tidak memiliki izin transaksi valas. Data yang digunakan adalah data panel tidak seimbang dengan jumlah observasi 206. Namun jumlah sampel dan jumlah observasi akan berubah pada pengujian hipotesis pertama dan ketiga. Hal tersebut disebabkan bank-bank yang sahamnya tidak aktif diperdagangkan dikeluarkan dari sampel. Jumlah bank amatan menyuust menjadi 25 dengan jumlah observasi sebanyak 136 dan 184 , tergantung pada proksi risikonya.

\section{Definisi Operasional Variabel}

\section{Diversifikasi Pendapatan}

Proksi diversifikasi pendapatan adalah pendapatan non-bunga yang dihitung dengan proporsi pendapatan non-bunga terhadap pendapatan operasional. Sumber pendapatan non-bunga terdiri dari dua jenis yaitu fee income dan trading income. Fee income dihitung dengan proporsi pendapatan provisi, komisi dan fee terhadap pendapatan operasional. Trading income dihitung dengan proporsi pendapatan yang bersumber dari transaksi valas dan kenaikan nilai surat-surat berharga terhadap pendapatan operasional. 


\section{Kinerja Bank}

Variabel dependen dalam penelitian ini adalah kinerja bank. Kinerja bank kemudian dibagi dua, yaitu kinerja yang dikur dengan data akuntansi dan data pasar. Proksi kinerja berdasarkan data pasar saham menggunakan proksi risiko sistematis, non-sistematis, risiko total, dan beta saham ${ }^{1}$. Proksi kinerja berdasarkan data akuntansi menggunakan deviasi standar ROA dan deviasi standar $\mathrm{ROE}^{2}$ sebagai proksi risiko. Proksi kinerja berdasarkan data akuntansi dikur dengan rasio Tobin's Q dan market equity- to-book equity (ME/BE), ROA dan rasio cost-to-income. Rasio Tobin's Q dihitung dengan rumus nilai pasar ekuitas dijumlahkan dengan nilai buku kewajiban kemudian dibagi dengan nilai buku aset. $\mathrm{ME} / \mathrm{BE}$ dihitung dengan rasio nilai pasar ekuitas dibagi nilai buku ekuitas.

\section{Model Pengujian Hipotesis}

Pengujian hipotesis pertama dan kedua dilakukan berdasarkan model berikut:

$\mathrm{Y}_{\mathrm{it}}=\beta_{1}+\beta_{2} \mathrm{NII}_{\mathrm{it}}+\beta_{3} \mathrm{FI}_{\mathrm{it}}+\beta_{4} \mathrm{TI}_{\mathrm{it}}$

$+\sum_{\mathrm{h}=1}^{4} \gamma_{\mathrm{h}} \mathrm{X}_{\text {hit }}+\varepsilon_{\text {it }}$

Sementara itu model untuk pengujian hipotesis ketiga adalah:

$\mathrm{Y}_{\mathrm{it}}=\beta_{3}+\beta_{4}$ Dsize $_{\mathrm{it}}+\varphi_{1} \mathrm{NII}_{\mathrm{it}}$
$+\varphi_{2} \mathrm{NII}_{\mathrm{it}} *$ Dsize $_{\mathrm{it}}+\sum_{\mathrm{h}=1}^{4} \gamma_{\mathrm{h}} \mathrm{X}_{\mathrm{hit}}+\varepsilon_{\mathrm{it}}$

$\mathrm{Y}_{\text {it }}$ merupakan variabel dependen risiko dan kinerja, NII $_{i t}$ merupakan proksi diversifikasi pendapatan yaitu pendapatan non-bunga, $\mathrm{FI}_{\text {it }}$ merupakan fee income dan $\mathrm{TI}_{\mathrm{it}}$ merupakan trading income. Dsize $e_{\mathrm{it}}$ merupakan variabel dummy ukuran bank, bernilai 1 jika bank besar dan 0 jika bank kecil. Klasifikasi bank besar dan bank kecil dilakukan berdasarkan nilai rata-rata logaritma natural (ln) total aset bankbank sampel pada setiap tahun. Jika nilai ln

\footnotetext{
${ }^{1}$ Model yang digunakan adalah model CAPM: $R_{\mathrm{it}}-\mathrm{R}_{\mathrm{rft}}=\alpha_{\mathrm{i}}$ $+\beta_{\mathrm{i}}\left(\mathrm{R}_{\mathrm{mt}}-\mathrm{R}_{\mathrm{rft}}\right)+\mathrm{e}_{\mathrm{it}}$ dengan data harga saham harian untuk setiap tahun penelitian. Proksi tingkat bunga bebas risiko adalah BI rate. Proksi market return dengan menggunakan data IHSG. Risiko sistematis dihitung dengan $\beta_{i}^{2} \sigma^{2}$ mt dan risiko non-sistematis dihitung dengan $\sigma_{\text {eit }}^{2}$. Risiko total adalah $\sigma_{\text {rit. }}$

2 Data yang digunakan adalah data ROA dan ROE kuartalan, sehingga deviasi standar ROA dan deviasi standar ROE tahunan adalah deviasi standar ROA dan ROE kuartalan dikalikan $\sqrt{4}$.
}

total aset bank di atas nilai rata-rata maka termasuk bank besar, jika di bawah nilai rata-rata termasuk bank kecil. Variabel $\mathrm{X}_{\text {hit }}$ merupakan variabel kontrol rasio equity to assets, rasio non performing loan, loan growth, dan profitabilitas (ROA).

\section{HASIL PENELITIAN DAN PEMBAHASAN}

\section{Statistik Deskriptif}

Berdasarkan hasil pengumpulan data terhadap variabel-variabel penelitian diperoleh proporsi pendapatan non-bunga dari seluruh observasi penelitian adalah $6,6 \%$ dengan proporsi fee income sebesar 4,2\% dan trading income $2,4 \%$. Selain itu nilai rata-rata equity-to-assets adalah $10,51 \%$ yang menunjukkan bahwa bank membiayai aset-asetnya dengan 89,5\% kewajiban. Rasio kredit bermasalah atau NPL bank-bank dalam observasi rata-rata sebesar 3,16\% dengan nilai maksimum 17\%. Pertumbuhan kredit rata-rata sebesar $28,15 \%$ dengan pertumbuhan kredit tertinggi sebesar $581 \%$. Nilai ratarata Tobin's Q adalah 1,09 dan market-to-bookequity adalah 1,96 . Sementara itu nilai rata-rata beta saham adalah 0,9 dengan nilai maksimum 1,59. Hasil selengkapnya dapat dilihat pada tabel 1.

\section{Pengujian Hipotesis}

Hasil pengujian terhadap hipotesis pertama dapat dilihat pada tabel 2 kolom (1) dan (5) yang menunjukkan bahwa pendapatan nonbunga tidak berpengaruh pada risiko sistematis dan beta saham. Namun pada kolom (3) dan (7) dapat dilihat pendapatan non-bunga berpengaruh negatif terhadap risiko non-sistematis dan risiko total bank, hipotesis $\mathrm{H}_{1 \mathrm{a}}$ terdukung. Hal tersebut sesuai dengan hasil studi Baele et al. (2007) pada bank-bank di Eropa dan studi Sawada (2013) pada bank-bank di Jepang. Pada bank-bank di Indonesia pendapatan non-bunga mampu memberikan manfaat semakin menurunnya risiko. Hal tersebut karena pendapatan non-bunga memiliki volatilitas yang lebih rendah dibandingkan pendapatan bunga. Potensi economies of scope masih tinggi karena penggunaan input secara bersamaan untuk produkproduk yang ditawarkan bank dapat meminimalkan risiko spesifik dan risiko total bank.

Hasil dari dua sumber pendapatan nonbunga lainnya dapat dilihat pada tabel 2 
spesifikasi (2), (4), (6), dan (8). Berdasarkan tabel tersebut pada kolom (4) dan (8) diperoleh bukti bahwa sumber pendapatan yang mampu menurunkan risiko non-sistematis dan risiko total bank adalah fee income, sehingga $\mathrm{H}_{1 \mathrm{~b}}$ terdukung. Hal ini berarti pendapatan yang bersumber dari provisi, komisi, dan fee adalah sumber pendapatan yang lebih stabil (Sawada, 2013). Kondisi yang bertentangan dengan kondisi di Amerika dan Eropa (Stiroh, 2006; Lapetit et al., 2008) disebabkan volatilitas pendapatan fee di Indonesia rendah.

Tabel 1. Statistik Deskriptif Variabel-Variabel Penelitian

\begin{tabular}{lcccccc}
\hline \multicolumn{1}{c}{ Variabel } & $\begin{array}{c}\text { Jumlah } \\
\text { Observasi }\end{array}$ & $\begin{array}{c}\text { Jumlah } \\
\text { bank }\end{array}$ & Rata-rata & $\begin{array}{c}\text { Deviasi } \\
\text { standar }\end{array}$ & Minimum & Maksimum \\
\hline Non-interest income (NII) & 206 & 27 & 0,0660 & 0,0499 & 0,0010 & 0,2370 \\
Fee income (FI) & 206 & 27 & 0,0420 & 0,0361 & 0,0000 & 0,1400 \\
Trading income (TI) & 206 & 27 & 0,0240 & 0,0236 & 0,0000 & 0,1130 \\
Equity to assets (E/A) & 206 & 27 & 0,1051 & 0,0352 & 0,0180 & 0,2480 \\
Non-performing loan (NPL) & 206 & 27 & 0,0316 & 0,0244 & 0,0000 & 0,1700 \\
Loan growth $(\mathrm{LG})$ & 206 & 27 & 0,2815 & 0,4725 & $-0,1670$ & 5,8100 \\
Return on assets $(\mathrm{ROA})$ & 206 & 27 & 0,0189 & 0,0125 & $-0,0190$ & 0,0590 \\
Tobin's $Q$ (TQ) & 205 & 27 & 1,0993 & 0,1213 & 0,8606 & 1,6079 \\
Market-to-book equity & 205 & 27 & 1,9638 & 1,0776 & 0,3524 & 5,9275 \\
Beta $\left(\beta_{\text {CAPM }}\right)$ & 137 & 25 & 0,9014 & 0,3964 & $-0,1950$ & 1,5931 \\
Systematic risk $\left(\beta^{2} \sigma_{m}{ }^{2}\right)$ & 137 & 25 & 0,0510 & 0,0545 & 0,0011 & 0,3255 \\
Unsystematic risk $\left(\sigma_{e}{ }^{2}\right)$ & 137 & 25 & 0,1828 & 0,1739 & 0,0343 & 1,2169 \\
\hline Sumber: Olahan
\end{tabular}

Sumber: Olahan data

Tabel 2. Hasil Regresi Pengaruh Diversifikasi Pendapatan terhadap Risiko

\begin{tabular}{|c|c|c|c|c|c|c|c|c|}
\hline \multirow[b]{2}{*}{ V. Independen } & \multicolumn{2}{|c|}{$\begin{array}{l}\text { Variabel dependen: } \\
\text { risiko sistematis }\left(\boldsymbol{\beta}^{2} \boldsymbol{\sigma}_{\mathrm{m}}{ }^{2}\right)\end{array}$} & \multicolumn{2}{|c|}{$\begin{array}{c}\text { Variabel dependen: } \\
\text { Risiko non-sistematis } \\
\left(\boldsymbol{\sigma}_{\mathrm{e}}^{2}\right)\end{array}$} & \multicolumn{2}{|c|}{$\begin{array}{l}\text { Variabel dependen: } \\
\boldsymbol{\beta}\end{array}$} & \multicolumn{2}{|c|}{$\begin{array}{l}\text { Variabel dependen: } \\
\text { Risiko total }\left(\boldsymbol{\sigma}_{\mathbf{i}}{ }^{2}\right)\end{array}$} \\
\hline & (1) & (2) & (3) & (4) & (5) & (6) & (7) & (8) \\
\hline $\begin{array}{l}\text { NII } \\
\text { (t-stat) }\end{array}$ & $\begin{array}{l}-0.068 \\
(-0.459)\end{array}$ & & $\begin{array}{l}-0.570 * * \\
(-2.030)\end{array}$ & & $\begin{array}{l}0.229 \\
(0.293)\end{array}$ & & $\begin{array}{l}-0.547^{*} \\
(-1.822)\end{array}$ & \\
\hline $\begin{array}{l}\text { FI } \\
\text { (t-stat) }\end{array}$ & & $\begin{array}{l}0.085 \\
(0.362)\end{array}$ & & $\begin{array}{l}-1.066 * * \\
(-2.533)\end{array}$ & & $\begin{array}{l}1.007 \\
(0.814)\end{array}$ & & $\begin{array}{l}-0.864 * \\
(-1.191)\end{array}$ \\
\hline $\begin{array}{l}\text { TI } \\
\text { (t-stat) }\end{array}$ & & $\begin{array}{l}-0.213 \\
(-0.933)\end{array}$ & & $\begin{array}{l}0.340 \\
(0.532)\end{array}$ & & $\begin{array}{l}-0.519 \\
(-0.433)\end{array}$ & & $\begin{array}{l}0.039 \\
(0.057)\end{array}$ \\
\hline $\begin{array}{l}\text { Equity to assets } \\
\text { (t-stat) }\end{array}$ & $\begin{array}{l}-0.366 \\
(-1.537)\end{array}$ & $\begin{array}{l}-0.377 \\
(-1.580)\end{array}$ & $\begin{array}{l}0.525 \\
(1.258)\end{array}$ & $\begin{array}{l}0.486 \\
(1.168)\end{array}$ & $\begin{array}{l}-0.923 \\
(-0.736)\end{array}$ & $\begin{array}{l}(-0.774) \\
(0.440)\end{array}$ & $\begin{array}{l}0.306 \\
(0.686)\end{array}$ & $\begin{array}{l}0.280 \\
(0.628)\end{array}$ \\
\hline $\begin{array}{l}\text { Non-performing } \\
\text { loan } \\
\text { (t-stat) }\end{array}$ & $\begin{array}{l}-0.337 \\
(-1.373)\end{array}$ & $\begin{array}{l}-0.284 \\
(-1.122)\end{array}$ & $\begin{array}{l}-0.452 \\
(-0.756)\end{array}$ & $\begin{array}{l}-0.483 \\
(-0.813)\end{array}$ & $\begin{array}{l}0.449 \\
(0.347)\end{array}$ & $\begin{array}{l}0.713 \\
(0.534)\end{array}$ & $\begin{array}{l}-0.007 \\
(-0.01)\end{array}$ & $\begin{array}{l}-0.027 \\
(-0.042)\end{array}$ \\
\hline $\begin{array}{l}\text { Loan growth } \\
\text { (t-stat) }\end{array}$ & $\begin{array}{l}0.036 \\
(1.293)\end{array}$ & $\begin{array}{l}0.035 \\
(1.252)\end{array}$ & $\begin{array}{l}0.029 \\
(0.418)\end{array}$ & $\begin{array}{l}0.029 \\
(0.416)\end{array}$ & $\begin{array}{l}0.210 \\
(1.428)\end{array}$ & $\begin{array}{l}0.205 \\
(1.389)\end{array}$ & $\begin{array}{l}0.055 \\
(0.733)\end{array}$ & $\begin{array}{l}(0.730) \\
(0.467)\end{array}$ \\
\hline $\begin{array}{l}\text { ROA } \\
\text { (t-stat) }\end{array}$ & $\begin{array}{l}-1.806 * * \\
(-2.486)\end{array}$ & $\begin{array}{l}-1.770^{* *} \\
(-2.428)\end{array}$ & $\begin{array}{l}-4.375 * * * \\
(-3.482)\end{array}$ & $\begin{array}{l}-3.911 * * * \\
(-3.046)\end{array}$ & $\begin{array}{l}-1.119 \\
(-0.293)\end{array}$ & $\begin{array}{l}-0.934 \\
(-0.243)\end{array}$ & $\begin{array}{l}-3.243 * * \\
(-2.417)\end{array}$ & $\begin{array}{l}-2.944 * * \\
(-2.134)\end{array}$ \\
\hline $\begin{array}{l}\text { Konstanta } \\
\text { (t-stat) }\end{array}$ & $\begin{array}{l}0.137 * * * \\
(4.557)\end{array}$ & $\begin{array}{l}0.132 * * * \\
(4.317)\end{array}$ & $\begin{array}{l}0.272 * * * \\
(4.439)\end{array}$ & $\begin{array}{l}0.268 * * * \\
(4.392)\end{array}$ & $\begin{array}{l}0.940 * * * \\
(5.943)\end{array}$ & $\begin{array}{l}0.916 * * * \\
(5.682)\end{array}$ & $\begin{array}{l}0.300 * * * \\
(4.579)\end{array}$ & $\begin{array}{l}0.297 * * * \\
(4.531)\end{array}$ \\
\hline $\mathrm{R}^{2}$ & 0.386 & 0.390 & 0.157 & 0.174 & 0.678 & 0.680 & 0.098 & 0.104 \\
\hline Jumlah Observasi & 136 & 136 & 136 & 136 & 136 & 136 & 136 & 136 \\
\hline Jumlah Bank & 25 & 25 & 25 & 25 & 25 & 25 & 25 & 25 \\
\hline
\end{tabular}

Kolom (1), (3), (5), dan (7) merupakan hasil regresi pendapatan non-bunga terhadap risiko sistematis, risiko nonsistematis, beta saham, dan risiko total. Kolom (2), (4), (6), dan (8) merupakan hasil regresi pendapatan fee dan pendapatan trading terhadap risiko sistematis, risiko non-sistematis, beta saham, dan risiko total. NII adalah proporsi pendapatan non-bunga terhadap pendapatan operasional. FI adalah proporsi fee income terhadap pendapatan operasional. TI adalah proporsi pendapatan trading terhadap pendapatan operasional. Risiko sistematis, non-sistematis, beta saham dan risiko total diestimasi dengan model CAPM menggunakan data harga saham harian. Variabel kontrol adalah equity to assets, non-performing loan, loan growth, dan ROA. Model pengujian hipotesis regresi risiko sistematis, dan beta saham menggunakan cross-section fixed effects. ***, **, * signifikan pada $1 \%, 5 \%$, dan $10 \%$. 
Pengujian hipotesis pertama dengan menggunakan proksi risiko akuntansi memberikan hasil yang tidak signfikan dari pengaruh diversfikasi pendapatan terhadap risiko sehingga tidak ditampilkan. Hasil pengujian pengaruh diversifikasi pendapatan terhadap kinerja bank dapat dilihat pada tabel 3. Berdasarkan tabel tersebut diperoleh bahwa diversifikasi pendapatan tidak berpengaruh terhadap kinerja yang diukur dengan nilai pasar. Namun pada kolom (5) dan (7), diversifikasi pendapatan berpengaruh positif terhadap profitabilitas dan berpengaruh negatif terhadap inefisensi biaya, $\mathrm{H}_{2}$ terdukung. Hal ini sesuai dengan studi Elsas et al. (2010) yang menyatakan bahwa terdapat manfaat economies of scope pada bank-bank yang melakukan diversifikasi. Berdasarkan hasil tersebut maka dapat diartikan nilai pasar bank tidak dipengaruhi aktivitas non-tradisional bank. Faktor yang mempengaruhi nilai pasar bank adalah tingkat leverage bank yaitu equity-to-assets. Semakin tinggi equity-to-assets semakin tinggi nilai pasar.
Faktor leverage dan NPL juga berpengaruh terhadap profitabilitas bank.

Pengujian hipotesis ketiga dapat dilihat pada tabel 4. Koefisien regresi interaksi tidak signifikan pada hampir semua proksi risiko, kecuali pada proksi risiko beta saham. Pada tabel 4 kolom (3) diperoleh koefisien interaksi pendapatan non-bunga dengan ukuran bank adalah signifikan. Hal ini berarti semakin tinggi diversifikasi pendapatan pada bank besar akan semakin rendah nilai beta saham.

Pengaruh diversifikasi pendapatan terhadap risiko sistematis beta saham lebih negatif pada bank besar daripada bank kecil. Penjelasan untuk penemuan studi ini adalah bahwa semakin besar ukuran bank, semakin baik sumber daya yang dimiliki, serta semakin tinggi pendapatan non-bunga. Semakin tinggi pendapatan non-bunga akan meminimalkan volatilitas pendapatan bank. Volatilitas pendapatan non-bunga lebih rendah dibanding pendapatan bunga.

Tabel 3. Hasil Regresi Diversifikasi Pendapatan Terhadap Kinerja Bank

\begin{tabular}{|c|c|c|c|c|c|c|c|c|}
\hline \multirow[b]{2}{*}{ V. Independen } & \multicolumn{2}{|c|}{$\begin{array}{c}\text { Variabel dependen: } \\
\text { Tobin's Q }\end{array}$} & \multicolumn{2}{|c|}{$\begin{array}{c}\text { Variabel dependen: } \\
\text { ME/BE }\end{array}$} & \multicolumn{2}{|c|}{$\begin{array}{c}\text { Variabel dependen: } \\
\text { ROA }\end{array}$} & \multicolumn{2}{|c|}{$\begin{array}{l}\text { Variabel dependen: } \\
\text { Cost-to-income }(\mathbf{C} / \mathbf{I})\end{array}$} \\
\hline & $(1)$ & $(2)$ & (3) & (4) & $(5)$ & (6) & (7) & $(8)$ \\
\hline $\begin{array}{l}\text { NII } \\
\text { (t-stat) }\end{array}$ & $\begin{array}{l}0.059 \\
(0.314)\end{array}$ & & $\begin{array}{l}0.624 \\
(0.356)\end{array}$ & & $\begin{array}{l}0.044 * * * \\
(2.965)\end{array}$ & & $\begin{array}{l}-0.273^{*} \\
(-1.884)\end{array}$ & \\
\hline $\begin{array}{l}\text { FI } \\
\text { (t-stat) }\end{array}$ & & $\begin{array}{l}0.320 \\
(1.128)\end{array}$ & & $\begin{array}{l}3.591 \\
(1.365)\end{array}$ & & $\begin{array}{l}0.027 \\
(1.114)\end{array}$ & & $\begin{array}{l}-0.205 \\
(-0.919)\end{array}$ \\
\hline $\begin{array}{l}\text { TI } \\
\text { (t-stat) }\end{array}$ & & $\begin{array}{l}-0.259 \\
(-0.811)\end{array}$ & & $\begin{array}{l}-3.117 \\
(-1.027)\end{array}$ & & $\begin{array}{l}0.055 * * \\
(2.282)\end{array}$ & & $\begin{array}{l}-0.341 \\
(-1.529)\end{array}$ \\
\hline $\begin{array}{l}\text { Equity to assets } \\
\text { (t-stat) }\end{array}$ & $\begin{array}{l}1.129 * * * \\
(4.329)\end{array}$ & $\begin{array}{l}1.147 * * * \\
(4.369)\end{array}$ & $\begin{array}{l}-2.656 \\
(-1.091)\end{array}$ & $\begin{array}{l}-2.464 \\
(-1.006)\end{array}$ & $\begin{array}{l}0.038^{*} \\
(1.886)\end{array}$ & $\begin{array}{l}0.033 \\
(1.525)\end{array}$ & $\begin{array}{l}-0.375^{*} \\
(-1.890)\end{array}$ & $\begin{array}{l}-0.376^{*} \\
(-1.889)\end{array}$ \\
\hline $\begin{array}{l}\text { Non-performing } \\
\text { loan } \\
\text { (t-stat) }\end{array}$ & $\begin{array}{l}-0.135 \\
(-0.386)\end{array}$ & $\begin{array}{l}-0.099 \\
(-0.282)\end{array}$ & $\begin{array}{l}-2.485 \\
(-0.752)\end{array}$ & $\begin{array}{l}-2.141 \\
(0.644)\end{array}$ & $\begin{array}{l}-0.045^{*} \\
(-1.726)\end{array}$ & $\begin{array}{l}-0.045 \\
(-1.629)\end{array}$ & $\begin{array}{l}0.671 * * * \\
(2.667)\end{array}$ & $\begin{array}{l}0.684 * * * \\
(2.694)\end{array}$ \\
\hline $\begin{array}{l}\text { Loan growth } \\
\text { (t-stat) }\end{array}$ & $\begin{array}{l}0.015 \\
(1.072)\end{array}$ & $\begin{array}{l}0.015 \\
(1.116)\end{array}$ & $\begin{array}{l}0.198 \\
(1.499)\end{array}$ & $\begin{array}{l}0.206 \\
(1.561)\end{array}$ & $\begin{array}{l}0.001 \\
(1.073)\end{array}$ & $\begin{array}{l}0.0012 \\
(1.184)\end{array}$ & $\begin{array}{l}0.004 \\
(0.368)\end{array}$ & $\begin{array}{l}0.004 \\
(0.369)\end{array}$ \\
\hline $\begin{array}{l}\text { ROA } \\
\text { (t-stat) }\end{array}$ & $\begin{array}{l}0.424 \\
(0.488)\end{array}$ & $\begin{array}{l}0.360 \\
(0.411)\end{array}$ & $\begin{array}{l}10.406 \\
(1.296)\end{array}$ & $\begin{array}{l}9.526 \\
(1.178)\end{array}$ & & & & \\
\hline $\begin{array}{l}\text { Konstanta } \\
\text { (t-stat) }\end{array}$ & $\begin{array}{l}0.965 * * * \\
(25.896)\end{array}$ & $\begin{array}{l}0.960 * * * \\
(25.459)\end{array}$ & $\begin{array}{l}1.996 * * * \\
(5.829)\end{array}$ & $\begin{array}{l}1.951 * * * \\
(5.643)\end{array}$ & $\begin{array}{l}0.131 * * * \\
(4.239)\end{array}$ & $\begin{array}{l}0.014 * * * \\
(5.205)\end{array}$ & $\begin{array}{l}0.874 * * * \\
(35.403)\end{array}$ & $\begin{array}{l}0.872 * * * \\
(34.819)\end{array}$ \\
\hline $\mathrm{R}^{2}$ & 0.109 & 0.116 & 0.029 & 0.040 & 0.108 & 0.771 & 0.720 & 0.720 \\
\hline Jumlah Observasi & 205 & 205 & 205 & 205 & 206 & 206 & 206 & 206 \\
\hline Jumlah Bank & 27 & 27 & 27 & 27 & 27 & 27 & 27 & 27 \\
\hline
\end{tabular}

Kolom (1), (3), (5), dan (7) merupakan hasil regresi pendapatan non-bunga terhadap kinerja dengan proksi Tobin's Q, $\mathrm{ME} / \mathrm{BE}$, ROA, cost-to-income. Kolom (2), (4), (6), dan (8) merupakan hasil regresi pendapatan fee dan pendapatan trading terhadap kinerja dengan proksi Tobin's Q, ME/BE, ROA, cost-to-income. NII adalah proporsi pendapatan nonbunga terhadap pendapatan operasional. FI adalah proporsi fee income terhadap pendapatan operasional. TI adalah proporsi pendapatan trading terhadap pendapatan operasional. Tobin's $\mathrm{Q}=$ (nilai pasar ekuitas + nilai buku kewajiban)/nilai buku aset. ME/BE merupakan rasio nilai pasar ekuitas/nilai buku ekuitas. Variabel kontrol adalah equity to assets, non-performing loan, loan growth, dan ROA. Model pengujian hipotesis data panel regresi kinerja pasar dan spesifikasi (5) menggunakan cross-section random effects, sedangkan kinerja akuntansi menggunakan crosssection fixed effects. $* * *, * *, *$ signifikan pada $1 \%, 5 \%$, dan $10 \%$.

Sumber: Olahan data 
Tabel 4. Hasil Regresi Interaksi Diversifikasi Pendapatan dan Ukuran Bank Terhadap Risiko

\begin{tabular}{|c|c|c|c|c|}
\hline & $\begin{array}{c}\text { Variabel dependen: } \\
\text { risiko sistematis } \\
\left(\boldsymbol{\beta}^{2} \boldsymbol{\sigma}_{\mathrm{m}}{ }^{2}\right) \\
\end{array}$ & $\begin{array}{c}\text { Variabel dependen: } \\
\text { Risiko non- } \\
\text { sistematis }\left(\boldsymbol{\sigma}_{\mathrm{e}}{ }^{2}\right) \\
\end{array}$ & $\begin{array}{c}\text { Variabel } \\
\text { dependen: } \\
\boldsymbol{\beta} \\
\end{array}$ & $\begin{array}{l}\text { Variabel dependen: } \\
\text { Risiko total }\left(\boldsymbol{\sigma}_{\mathbf{i}}^{2}\right)\end{array}$ \\
\hline V. Independen & $(1)$ & $(2)$ & (3) & (4) \\
\hline NII & -0.136 & -0.687 & $4.013^{*}$ & -0.844 \\
\hline (t-stat) & $(-0.380)$ & $(-0.643)$ & (1.953) & $(-0.728)$ \\
\hline Dsize & 0.022 & $-0.157 * * *$ & $0.449 * * *$ & $-0.140 * *$ \\
\hline (t-stat) & $(1.125)$ & $(-2.703)$ & $(2.976)$ & $(-2.226)$ \\
\hline NII*Dsize & 0.067 & 0.589 & ${ }^{3}-4.550 * *$ & 0.716 \\
\hline (t-stat) & $(0.177)$ & $(0.521)$ & $(-2.063)$ & $(0.584)$ \\
\hline Equity to assets & -0.157 & 0.047 & -0.383 & -0.127 \\
\hline (t-stat) & $(-1.041)$ & $(0.104)$ & $(-0.364)$ & $(-0.262)$ \\
\hline Non-performing loan & 0.291 & 0.027 & 1.389 & 0.411 \\
\hline (t-stat) & $(1.452)$ & $(0.046)$ & $(1.156)$ & $(0.634)$ \\
\hline Loan growth & 0.017 & 0.024 & 0.172 & 0.050 \\
\hline (t-stat) & $(0.753)$ & $(0.354)$ & (1.335) & $(0.683)$ \\
\hline ROA & $0.783^{*}$ & $-2.549^{*}$ & 4.145 & -1.711 \\
\hline (t-stat) & (1.738) & $(-1.899)$ & $(1.268)$ & $(-1.176)$ \\
\hline Konstanta & 0.026 & $0.356^{* * * *}$ & $0.402 * *$ & $0.379 * * *$ \\
\hline (t-stat) & (1.005) & $(4.622)$ & $(2.275)$ & $(4.543)$ \\
\hline $\mathrm{R}^{2}$ & 0.109 & 0.224 & 0.122 & 0.143 \\
\hline Jumlah Observasi & 136 & 136 & 136 & 136 \\
\hline Jumlah Bank & 25 & 25 & 25 & 25 \\
\hline
\end{tabular}

Kolom (1), (2), (3), dan (4) merupakan hasil regresi interaksi pendapatan non-bunga dengan Dsize terhadap risiko sistematis, risiko non-sistematis, beta saham, dan risiko total. NII adalah proporsi pendapatan non-bunga terhadap pendapatan operasional. Dsize bernilai 1 jika bank besar dan 0 jika bank kecil. Risiko sistematis, non-sistematis, beta saham dan risiko total diestimasi dengan model CAPM menggunakan data harga saham harian. Model pengujian menggunakan OLS. $* * *, * *, *$ signifikan pada $1 \%, 5 \%$, dan $10 \%$.

Sumber: data diolah

\section{PENUTUP}

Berdasarkan hasil penelitian dapat disimpulkan bahwa diversifikasi pendapatan mampu menurunkan risiko non-sistematis dan risiko total bank. Sumber pendapatan non-bunga yang mampu menurunkan risiko adalah pendapatan fee. Diversifikasi mampu menurunkan risiko non-sistematis, meningkatkan profitabilitas, dan menurunkan inefisiensi biaya namun tidak signifikan meningkatkan nilai pasar bank.

Sumber pendapatan yang mampu meningkatkan profitabilitas bank adalah pendapatan trading. Selain itu, tidak ditemukan adanya pengaruh yang lebih negatif dari diversifikasi pendapatan terhadap risiko sistematis, risiko non-sistematis, risiko total, dan risiko akuntansi pada bank besar. Risiko yang lebih

\footnotetext{
${ }^{3}$ Regresi tambahan dilakukan pada setiap proksi risiko, $y_{\text {it }}$ $=\mathrm{a}+\mathrm{b}_{1} \mathrm{NII}_{\mathrm{it}}+\mathrm{b}_{2}$ Dsize $_{i t}+\mathrm{e}_{\mathrm{it}}$ dengan $\mathrm{y}_{\mathrm{it}}$ merupakan proksi risiko total dan beta saham. Regresi ini untuk mengetahui pengaruh variabel non-interest income dan ukuran bank terhadap risiko. Hasilnya diperoleh bahwa koefisien $b_{1}$ tidak signifikan dengan nilainya adalah -0.239 pada risiko total, dan -0.130 pada beta. Koefisien $b_{2}$ adalah -0.129 signifikan untuk risiko total; 0.365 signifikan pada beta.
}

rendah diperoleh bank besar dengan semakin meningkatnya diversifikasi pendapatan hanya berlaku pada beta saham.

Penelitian ini hanya sebatas pada regresi non-linear sehingga tidak dapat diketahui proporsi maksimal yang masih mampu menurunkan risiko bank. Penelitian selanjutnya akan lebih baik jika menggunakan regresi nonlinear karena studi sebelumnya (Baele et al., 2007; Sawada, 2013) menemukan hubungan non-linear dari diversifikasi pendapatan dan risiko. Sampel yang digunakan pada penelitian ini adalah bank-bank yang terdaftar di Bursa Efek Indonesia. Penelitian berikutnya perlu menggunakan sampel seluruh bank yang menjalankan bisnis di Indonesia sehingga dapat diketahui pengaruh aktivitas diversifikasinya terhadap risiko. Variabel ukuran bank tidak mampu menjadi faktor yang memperkuat atau memperlemah pengaruh diversifikasi pendapatan terhadap risiko. Tantangan bagi peneliti selanjutnya adalah menemukan faktor apa yang mampu memperkuat atau memperlemah hubungan diversifikasi pendapatan dan risiko. 


\section{DAFTAR PUSTAKA}

Acharya V.V., dan Hasan I, S.A. 2002. The effects of focus and diversification on bank risk and return: evidence from individual bank loan portfolios. Discussion Paper No. 3252, Centre for Economic Policy Research, March.

Alhassan, A.L. 2015. Income diversification and bank efficiency in an emerging market. Managerial Finance, 41(12); 1318 - 1335.

Baele, L., O.D., Jonghe, dan RV. Vennet. 2007. Does the stock market value bank diversification?. Journal of Banking and Finance. 31. 1999-2023.

Bank Indonesia. 2013. Statistik Perbankan Indonesia Desember 2012. Departemen Perizinan dan Informasi Perbankan: Bank Indonesia.

Bank Indonesia. 2013. Direktori Perbankan Indonesia 2013. Volume (14). Departemen Perizinan dan Informasi Perbankan. Bank Indonesia.

Berger, A. N., I. Hasan, dan M. Zhou. 2010. The effects of focus versus diversification on bank performance: evidence from chinese banks. Journal of Banking and Finance. 34. 1417-1435.

Brighi, P., dan Venturelli, V. 2014. How do income diversification, firm size and capital ratio affect performance? evidence for bank holding companies. Applied Financial Economics. 24(21); 1375-1392.

Chiorazzo, V., Milani, C., dan Salvini. F. 2008. Income diversification and bank performance: evidence from italian banks. Journal of Financial Services Research. 33; 181-203.

Deng, S.E., Elyasani, E., dan Mao, X.C. 2007, Diversification and the cost of debt of bank holding companies. Journal of Banking and Finance, 31(8); 2453-2473.

Elsas, R., A. Hackethal, dan M. Holzhäuser. 2010. The anatomy of bank diversification. Journal of Banking and Finance. 34. 1274-1287.

Elyasiani, E., dan Wang, Y. 2012. Bank holding company diversification and production. efficiency. Applied Financial Economics. 22(17); 1409-1428.

Hidayat, W.Y., M. Kakinaka, and H. Miyamoto. 2012. Bank risk and noninterest income activities in the indonesian banking industry. Journal of Asian Economics. 23. 335-343.

Kusuma, D. R. 2012. Diversifikasi Pendapatan dan Risiko Perbankan di Indonesia. Tesis Magister Sains Fakultas Ekonomika dan Bisnis Universitas Gadjah Mada.

Laeven, L., dan R. Levine. 2007. Is there a diversification discount in financial conglomerates?. Journal of Financial Economics. 85. 331-367.

Lapetit, L., E. Nys, P. Rous, dan A. Tarazi. 2008. Bank income structure and risk: an empirical analysis of European banks. Journal of Banking and Finance. 32. 1452-1467.

Mercieca, S., K. Schaeck, and S. Wolfe. 2007. Small European banks: benefits from diversification? Journal of Banking and Finance. 31. 1975-1998.

Sanya, S., dan Wolve, S. 2011. Can banks in emerging economies benefit from revenue diversification? Journal of Financial Service Research. 40; 79-101.

Sawada, M. 2013. How does the stock market value bank diversification? empirical evidence from japanese bank. PacificBasin Finance Journal. 25. 40-61.

Stiroh, K.J. 2006. A portfolio view of banking with interest and noninterest activities. Journal of Money, Credit and Banking. 38. 1351-1361.

Stiroh, K.J., and A. Rumble. 2006. The dark side of diversification: the case of US financial holding companies. Journal of Banking and Finance. 30. 2131-2161.

Vennet, V.R. 2002. Cost and profit efficiency of financial conglomerates and universal banks in Europe. Journal of Money, Credit and Banking. 34(1); 254-282.

Zhou, K. 2014. The effect of income diversification on bank risk: evidence from China. Emerging Markets Finance and Trade. 50(3); 201-2013. 